\title{
Influence of Brand Loyalty in Telecommunication Sector in Pakistan
}

\author{
Naveed Anjum \\ Research Scholar, Department of Management Sciences \\ The Islamia University of Bahawalpur, Pakistan
}

Muhammad Rizwan

Lecturer, Department of Management Sciences,

The Islamia University of Bahawalpur, Pakistan.

Email: rizwan.arshad@iub.edu.pk

Mubashir Khaleeq

Research Scholar, Department of Management Sciences

The Islamia University of Bahawalpur, Pakistan

Hafiz Muhammad Wasif Rasheed

MS Scholar, Department of Management Sciences

The Islamia University of Bahawalpur, Pakistan

Accepted: September 13, $2013 \quad$ DOI: 10.5296/jpag.v3i3.6217

\begin{abstract}
Brands play a very important role in consumer markets. They bridge a relationship between the consumers and the company. Brand loyalty is a consumer's preference to purchase a particular product or service at first or repeatedly in a competitive market. The general purpose of this study is to investigate the factors leading to brand loyalty in service sector. Specifically, we are concerned to observe the factors affecting brand loyalty in telecommunication sector of Pakistan. The sample size of 150 is taken through convenient sampling method. The survey method is used to collect the data from the respondents through self-administered questionnaire. The regression analysis approved the significant positive relationship of the proposed factors with brand loyalty.
\end{abstract}

Keywords: Brand Communication, Brand Trust, Brand Loyalty, Customer Satisfaction, perceived Quality. 


\section{Introduction}

The advancement in technology, the saturation of markets, globalization and intense competition has urged the companies to focus more and more on brand loyalty. For this, we find an attractive space to conduct research on this burning issue. Today, the markets are very much mature, the organizations find it very difficult to retain and attract the prosperous customers due to intense competition. These factors urge us to have conducted a research on some of the most influential antecedents of brand loyalty namely perceived quality, customer satisfaction. The brand communication and brand name put an effect on Brand trust that ultimately leads to brand loyalty. The study is conducted to explore the relationship of previously described variables with brand loyalty so that explaining how they create brand loyalty with their collective impact. We selected telecommunication sector of Pakistan to test these variables whether they have the effect on the brand loyalty as proposed. The telecommunication sector is one of the fastest growing sectors in Pakistan. According to a recent study, there are almost 80 million mobile phone users in Pakistan and yet the number is growing rapidly. It is predicted that after 10 years or less, every second Pakistani will have a mobile phone.

In modern marketing world, the brand is a term, symbol, name, logo, design or combination of them that differentiates any product or service from those of competitors' (Kotler, 1997).

In previous researches, the researchers had been taking the measure of repurchase behavior as brand loyalty but in recent days, measuring true loyalty is the best way of measuring brand loyalty (Bennett and Rundle-Thiele, 2000). Two indicators are added by Day (1996) affection and action for brand loyalty and divided brand loyalty into spurious brand loyalty and actual brand loyalty. In spurious brand loyalty, the consumer has no other choice of brand except the current one but in actual brand loyalty, the consumer shows a firm attitudinal and psychological binding with the specific product or service among the other similar brands.

The past researches show that trust is very essential for the development of brand loyalty (Berry, 1995; Reicheld\&Schefter, 2000; Dyson, Farr \& Hollis, 1996; Morgan and Hunt 1994, Chaudhuri and Holbrook, 2001 ).. Consumers trust in brand is based on positive beliefs regarding the expectations of the consumers in a product or service.

A brand name is just like a trade mark.Developing a brand name is an expensive process (Kohli and Thakor, 1997). It is veru necessary that brand name must be easy to remember and should be very unique (Keller, 2008). The brand name causes a competitive advantage over competitors (Zeugner -Roth, et al., 2008). Consumers perceive the products from an overall perspective, relating with the brand name, all the characteristics and satisfaction observed by the purchase and use of the product.

The brand communication is the first and foremost element in managing brand relationship with the consumers (Panda, 2004, p.9). The brand communication is also very important in launching new products (Pearson, 1996; Duncan and Moriarty, 1998). Brand communication has been consistently found to play an important role in creating positive brand attitudes (Kempf and Smith,1998). 
A number of empirical studies show that customer satisfaction plays a very important role in developing repurchase behavior (Bennett et al., 2007, et al., 1999; Russell Oliver, 1980; Pritchard ). Satisfaction increases loyalty when brand loyalty is measured in a number of successive purchases of the same brand (LaBarbera and Mazursky, 1983).

The degree of excellence of a product or service is called quality. It is also defined as fitness for purpose. The product quality also differentiates the product or service in competitive world (Zeithaml, 1988 ,Aaker, 1996;Yoo, Donthu, \& Lee, 2000; Low \& Lamb, 2000). when firms identify then satisfy the needs, wants and demands of customers, they find a positional advantage over competitors as reflected in growing sales and building loyal customers (Hult and Ketchen, 2001; Zhu and Nakata, 2007).

The results of our research show that there is a strong positive relationship between the brand loyalty and the independent variables of our proposed model. This research will open the doors for future researchers to understand and explore the markets in terms of brand loyalty. This research will provide a better understandability of the customers and markets for the organizations competing in such a mature and intensive competitive market.

\section{LITERATURE REVIEW}

\subsection{Brand Loyalty}

The brand loyalty is most completely defined by Jacoby and Olson (1970). They define brand loyalty as the mental purchase process resulted from nonrandom and long existence behavior of the customers. In simple words, we can say that brand loyalty is a repurchase behavior of customers towards a specific product or service. The consideration of brand loyalty is concerned when a customer has choice among various brands. In previous researches, the researchers had been taking the measure of repurchase behavior as brand loyalty but in recent days, measuring true loyalty is the best way of measuring brand loyalty (Bennett and Rundle-Thiele, 2000). It is observed that brand loyalty covers both affective loyalty and action loyalty simultaneously (Baldinger and Rubinson) (1996). The affective loyalty Groth and McDaniel (1993) confirmed that affective loyalty shows consumer loyalty to a specific brand all the way. Oliver (1999) classified brand loyalty into four parts: cognitive loyalty, affective loyalty, conation loyalty and action loyalty. There are so many factors that lead to brand loyalty. Two indicators are added by Day (1996) affection and action for brand loyalty and divided brand loyalty into spurious brand loyalty and actual brand loyalty. In spurious brand loyalty, the consumer has no other choice of brand except the current one but in actual brand loyalty, the consumer shows a firm attitudinal and psychological binding with the specific product or service among the other similar brands. The advancement in technology, the saturation of markets, globalization and intense competition has urged the companies to focus more and more on brand loyalty. So brand loyalty may confirm the organizational growth and above average profits. In simple words, we can say that the purpose of brand loyalty is to attract new customers and retaining the old loyal customers (Rizwan et al., 2013). 


\subsection{BRAND TRUST}

The willingness of the consumer to depend on the ability of the brand to perform its prescribed functions is called brand trust (Moormal et al 1993, p. 315). The brand trust is an intentional confidence shown by the consumer on a specific product or service to exchange the partner's trustworthiness (Dwyer and LaGace., 1986). Doney and Cannon (1997), Zaltman, and Deshpande (1992) proposed that trsust is only relevant in the situation of uncertainty. The consumers rely on the trusted brands only.

There are different fields of studies in which trust has been very important in proving the relationships such as sociology (e.g., Lewis and Weigert 1985), economics (e.g., Dasgupta 1988), psychology (e.g., Deutsch 1960; Larzelere and Huston 1980; Rempel et al. 1985; Rotter 1980), management (e.g., Barney and Hausen 1994) and marketing (e.g., Andaleeb 1992; Dwyer et al. 1987; Morgan and Hunt 1994). The past researches show that trust is very essential for the development of brand loyalty (Berry, 1995; Reicheld\&Schefter, 2000; Dyson, Farr \& Hollis, 1996; Morgan and Hunt 1994, Chaudhuri and Holbrook, 2001 ). In marketing, the brand trust has got a great attention (Schurr, \& Oh, 1987, Andaleeb, 1992; Dwyer,; Morgan \& Hunt, 1994).

Barney and Hansen (1994) confirmed that trust is the mutual confidence that no party in an exchange will exploit another's vulnerability. Consumers trust in brand is based on positive beliefs regarding the expectations of the consumers in a product or service.

\subsection{BRAND NAME}

A brand name is just like a trade mark. It is quite often interchangeable with "Brand". Brand Names come in many styles. Some of these are: Initialism: A name made of initials such, as UPS or IBM. Descriptive: Names that describe a product benefit or function, such as Whole Foods or Airbus. Alliteration and rhyme: Names that are fun to say and stick in the mind, such as Reese's Pieces or Dunkin' Donuts. Founders' names: Using the names of real people, (especially a founder's name), such as Hewlett-Packard, Dell or Disney.

Developing a brand name is an expensive process (Kohli and Thakor, 1997). It is very necessary that brand name must be easy to remember and should be very unique (Keller, 2008). The brand name causes a competitive advantage over competitors (Zeugner -Roth, et al., 2008). The brand name is actually useful for communicating the excellent features of the products and services. The consumers may prefer the most famous and renown brands. According to Kohli and Thakor (1997), brand name is the development of an image or the development of a brand identity and is an expensive and time consuming process.

The brand name or "Brand" plays a very important role to create brand loyalty. Brand name isimportant for the firm to attract customers to purchase the product and influence repeat purchasing behavior. Consumers perceive the products from an overall perspective, relating with the brand name, all the characteristics and satisfaction observed by the purchase and use of the product. 


\subsection{BRAND COMMUNICATION}

The brand communication is the process of decreasing the gap between the consumer and his/her perception regarding the product and service. The purpose of brand communication is exposing the product or service to the audience so that the consumer would be fully aware of the product or service present in the market. Extensive advertising campaigns through print and electronic media is used for brand communication. The brand communication is the first and foremost element in managing brand relationship with the consumers (Panda, 2004, p.9). The brand communication is also very important in launching new products (Pearson, 1996; Duncan and Moriarty, 1998). Brand communication has been consistently found to play an important role in creating positive brand attitudes (Kempf and Smith, 1998).

\subsection{CUSTOMER SATISFACTION}

The customer satisfaction is the term widely used in marketing. It is a measure to identify how the product or service meets the expectations of the consumers regarding a particular product or service. A number of empirical studies show that customer satisfaction plays a very important role in developing repurchase behavior (, Russell Bennett et al., 2007 Oliver, 1980; Pritchardet al., 1999). Satisfaction increases loyalty when brand loyalty is measured in a number of successive purchases of the same brand (LaBarbera and Mazursky, 1983). The customer satisfaction can be both cognitive and emotional, Rodriguez del Bosque and San Martin (2008). There are two common formulations of satisfaction: overall satisfaction and transaction specific satisfaction. Whenever, there is an immediate post purchase evaluation it is termed as post purchase satisfaction (Oliver,1993). The overall satisfaction is the judgment of all the parameters of expectations and the actual satisfaction from a particular product or service (Bitner\&Hubbert, 1994).

\subsection{PERCEIVED PRODUCT QUALITY}

The degree of excellence of a product or service is called quality. It is also defined as fitness for purpose. The product quality also differentiates the product or service in competitive world (Zeithaml, 1988 ,Aaker, 1996; Yoo, Donthu, \& Lee, 2000; Low \& Lamb, 2000). There are so many dimensions of product or service quality (Chao, 2008). The Nordic School's view of service quality consists of two dimensions: functional quality and technical quality and (Gronroos, 1984). On the other hand, when firms identify then satisfy the needs, wants and demands of customers, they find a positional advantage over competitors as reflected in growing sales and building loyal customers (Hult and Ketchen, 2001; Zhu and Nakata, 2007). One reason is that customers perceive that the firm offers greater value in its products and services. As satisfied customers are likely to be loyal, the notion of positional advantage suggests that greater customer orientation corresponds with the reinforcement of the link between satisfaction and loyalty. 


\section{Macrothink

\section{HYPOTHESIS AND MODEL}

\subsection{HYPOTHESIS}

H1: There is a significant relationship between perceived quality \& customer satisfaction.

H2: There is a significant relationship between brand name \& brand trust.

H3: There is a significant relationship between brand communication \& brand trust.

H4: There is a significant relationship between perceived quality and brand loyalty.

H5: There is a significant relationship between customer satisfaction \& brand loyalty.

H6: There is a significant relationship between brand trust \& brand loyalty.

\subsection{CONCEPTUAL MODEL}

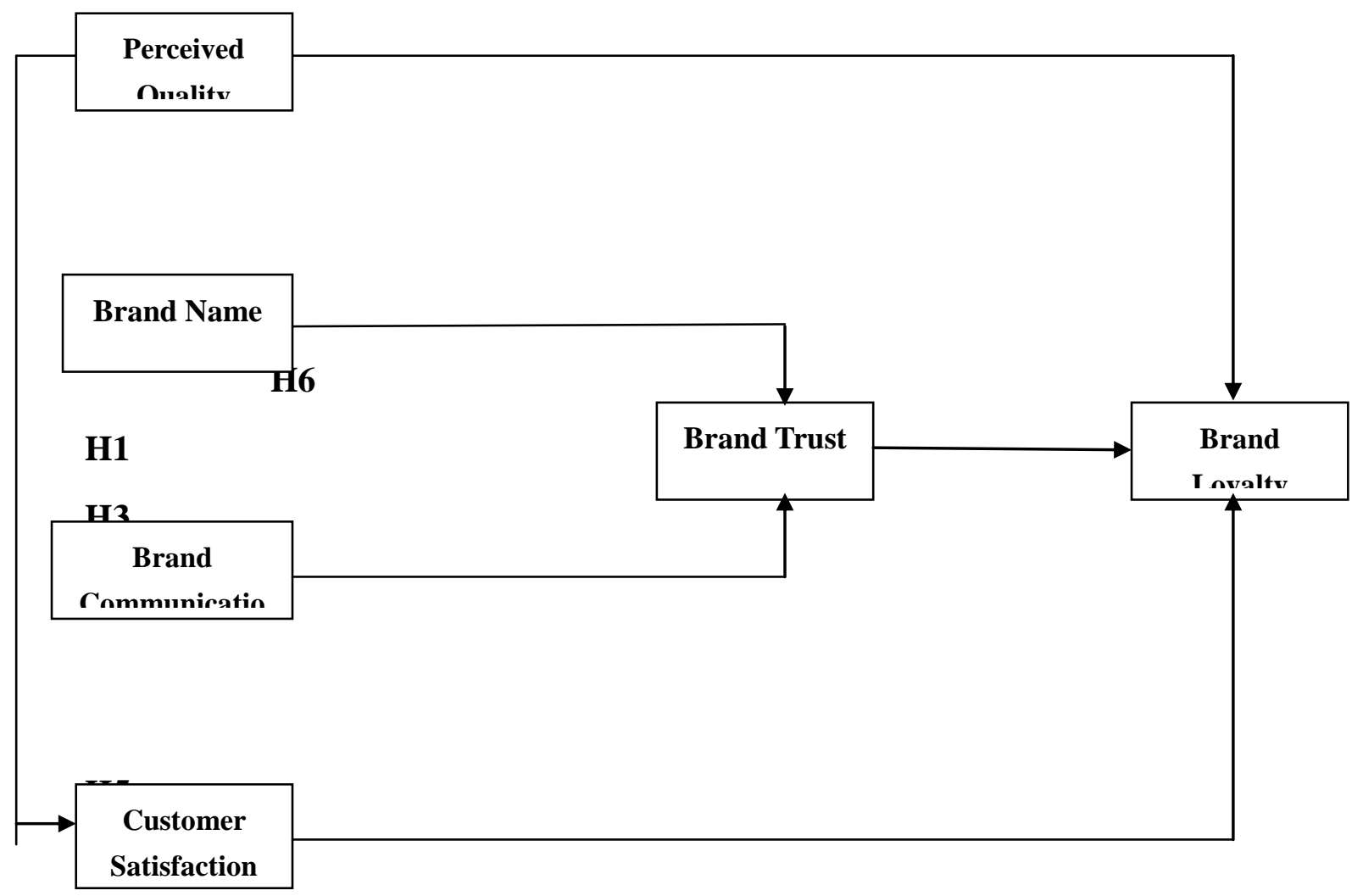

\section{RESEARCH METHODOLOGY}

This research is causal in nature. The causal research defines the relationship between two variables. The causal research in marketing identifies the cause and effect between people. The causal research in social sciences is very important. The objective of the causal 
research is to determine which variable might be causing a certain behavior i.e. whether there is a cause and effect relationship between variables. This type of research is very complex and the researcher is never completely certain that there are no other factors that influencing the causal relationship especially when dealing with people's attitude and motivations.

\subsection{SAMPLE/DATA:}

We collected data in five different cellular phone service providers' from the customers using the services of these cellular phone services in Bahawalpur (Pakistan). Those mobile services users were focused who have been using the services for at least three years.

The convenient sampling technique is used to collect the data. In convenience sampling technique, the relevant information is conveniently available (Zikmund, 1997).

A self-administered questionnaire was distributed among 180 mobile phone users in the locality of Bahawalpur City (Pakistan). Out of these 30questionnaires were found incomplete or not responded. So the final sample size for this particular study is 150 .

It has ensured that the sample members possess the two basic qualifications to participate in the self-administered questionnaire. First, the sample member should be using mobile phone service for at least three years. Second, he should be using only the one cellular phone service at a time during the said time period.

\subsection{INSTRUMENTS AND MEASURES}

The instruments and measures is an important part of the survey method. The instrument and measures of the current study focuses two major purposes: First, the relationship of different variables in brand loyalty or cellular service users. Second, the information about different characteristics of the respondents that can be used to measure the variations in different categories is collected.

There are two parts of survey instruments. The first part includes the personal and demographic variables regarding the information of the respondents. The personal information of the respondent includes gender, age, income, education, the choice of the cellular service.

The second part includes the variables that we are going to measure in our study Table 1. These variables include Brand loyalty, Perceived Quality, Customer Satisfaction, Brand Name, Brand Trust, and Brand Communication. All these variables are derived from the past researches and literatures. The variable of Customer Satisfaction has two items, perceived quality and brand name have four items each and Brand Trust and Brand Communication have five items each. 


\begin{tabular}{|c|c|c|c|}
\hline No. & Variable & Items & Reference \\
\hline 01 & Brand Loyalty & $\begin{array}{l}\text { 1. This Brand would be my first choice. } \\
\text { 2. I consider myself to be loyal to this } \\
\text { Brand } \\
\text { 3. I will not switch to other mobile service } \\
\text { if the same service is available in the } \\
\text { market. }\end{array}$ & $\begin{array}{c}\text { Yoo and } \\
\text { Donthu (2001) }\end{array}$ \\
\hline 02 & $\begin{array}{l}\text { Perceived } \\
\text { Quality }\end{array}$ & $\begin{array}{l}\text { 1. It is likely that this mobile service is of } \\
\text { very high quality. } \\
\text { 2. It is likely that this mobile service is of } \\
\text { very consistent quality. } \\
\text { 3. It is likely that this mobile service offers } \\
\text { excellent features. } \\
\text { 4. It is likely that this mobile service is very } \\
\text { reliable. }\end{array}$ & Aaker (1991) \\
\hline $\mathbf{0 3}$ & $\begin{array}{l}\text { Customer } \\
\text { Satisfaction }\end{array}$ & $\begin{array}{l}\text { 1. Over all I am satisfied with specific } \\
\text { experience of this mobile service. } \\
\text { 2. I am satisfied with my decision to } \\
\text { purchase this mobile service. }\end{array}$ & Irwin (2001). \\
\hline 04 & Brand Name & $\begin{array}{l}\text { 1. This mobile service is reputable. } \\
\text { 2. The mobile service name and image } \\
\text { attract me to purchase. } \\
\text { 3. I select this mobile service regardless of } \\
\text { price. } \\
\text { 4. This mobile service reflects my own } \\
\text { personality. }\end{array}$ & $\begin{array}{l}\text { Wong Foong } \\
\text { Yee and } \\
\text { Yahyahsidek } \\
2008\end{array}$ \\
\hline 05 & Brand Trust & $\begin{array}{l}\text { 1. I trust this mobile service. } \\
\text { 2. I rely on this mobile service. } \\
\text { 3. This mobile service is safe as it maintains } \\
\text { and ensures my confidentiality and } \\
\text { privacy. } \\
\text { 4. This is an honest brand as it charges } \\
\text { fairly on its services. } \\
\text { 5. This mobile service meets my } \\
\text { expectations. }\end{array}$ & $\begin{array}{l}\text { Matzler et al. } \\
\text { 2008; } \\
\text { Morgan \& } \\
\text { Hunt , } 1994\end{array}$ \\
\hline 06 & $\begin{array}{l}\text { Brand } \\
\text { Communication }\end{array}$ & $\begin{array}{l}\text { 1. I react favorably to the advertising and } \\
\text { promotion of this mobile service. } \\
\text { 2. I feel positive towards the advertising and } \\
\text { persona of this brand. } \\
\text { 3. The advertising and promotions of this } \\
\text { brand are very informative and appealing. } \\
\text { 4. I am happy with the advertising and } \\
\text { promotions of this mobile service. } \\
\text { 5. I like the advertising and promotions of } \\
\text { this mobile setvice. }\end{array}$ & $\begin{array}{l}\text { CemalZahir et } \\
\text { al, } 2011 \\
\text { w.macrothink.org/jpag }\end{array}$ \\
\hline
\end{tabular}




\section{Macrothink}

\subsection{PROCEDURE}

The proposed questionnaire was distributed among 180 respondents in Bahawalpur, Pakistan. These respondents were selected on the basis of the criteria discussed earlier. Before giving the questionnaire to the respondents, the purpose of our study was communicated to the respondents so that they could easily fill in the questionnaire without any ambiguity. A total of 150 respondents responded positively and rest of the questionnaires was not included in further analysis as they were found incomplete. After having completed the questionnaires, these questionnaires were coded and entered into SPSS Software sheet for further statistical analysis.

\subsection{RELIABILITY ANALYSIS}

Table 2:Reliability of Measurements Instrument.

\begin{tabular}{|l|l|l|}
\hline Scales & Items & Cronbach's Alpha \\
\hline Brand Loyalty & 3 & 0.527 \\
Perceived Quality & 4 & 0.601 \\
Customer Satisfaction & 2 & 0.515 \\
Brand Name & 4 & 0.729 \\
Brand Trust & 5 & 0.749 \\
Brand Communication & 5 & 0.827 \\
\hline
\end{tabular}

\section{RESULTS OF ANALYSIS}

Profile of the respondents

\begin{tabular}{|l|l|l|l|}
\hline Variable & Category & Frequency & Percentage \\
\hline Gender & Male & 101 & 67.3 \\
& Female & 49 & 32.7 \\
\hline \multirow{3}{*}{ Status } & Student & 76 & 50.7 \\
& Employed & 49 & 32.7 \\
& Unemployed & 9 & 6 \\
\hline
\end{tabular}




\begin{tabular}{|c|c|c|c|}
\hline & House Wife & 7 & 4.7 \\
\hline Education & $\begin{array}{l}\text { Matriculation } \\
\text { Inter } \\
\text { Graduation } \\
\text { Master } \\
\text { M.Phil/Phd }\end{array}$ & $\begin{array}{l}6 \\
8 \\
51 \\
70 \\
15\end{array}$ & $\begin{array}{l}4 \\
5.3 \\
34 \\
46.7 \\
10\end{array}$ \\
\hline Income (Rs) & $\begin{array}{l}\text { Below } 15000 \\
15000-25000 \\
25000-35000 \\
35000-45000 \\
\text { Above } 45000 \\
\text { Missing }\end{array}$ & $\begin{array}{l}44 \\
21 \\
18 \\
14 \\
25 \\
28\end{array}$ & $\begin{array}{l}29.3 \\
14 \\
12 \\
9.3 \\
16.7 \\
18.7\end{array}$ \\
\hline Age & $\begin{array}{l}\text { 15-20 Years } \\
\text { 20-25 Years } \\
\text { 25-30 Years } \\
\text { Above } 30 \text { Years }\end{array}$ & $\begin{array}{l}11 \\
68 \\
32 \\
39\end{array}$ & $\begin{array}{l}7.3 \\
45.3 \\
21.3 \\
26\end{array}$ \\
\hline $\begin{array}{l}\text { Cellular } \\
\text { Phone Service }\end{array}$ & $\begin{array}{l}\text { Mobilink } \\
\text { Ufone } \\
\text { Telenor } \\
\text { Zong } \\
\text { Warid } \\
\text { Others }\end{array}$ & $\begin{array}{l}35 \\
59 \\
23 \\
18 \\
15 \\
0\end{array}$ & $\begin{array}{l}23.3 \\
39.3 \\
15.3 \\
12 \\
10 \\
0\end{array}$ \\
\hline
\end{tabular}

\subsection{HYPOTHESIS TESTING}

\subsubsection{Brand Name, Brand Communication and Brand Trust}

The regression results of the study confirm the significant relationship of brand name and brand communication on brand trust. The Beta values of Brand Name, Brand Communication 
are respectively $(\beta=0.354),(\beta=0.256)$ and the significant values are $(\mathrm{p}<0.001),(\mathrm{p}<0.01)$. The value of Adjusted R Square for the above relation is 0.251 .

From the above analysis, the hypothesis $\mathrm{H} 2$ and $\mathrm{H} 3$ are proved.

\subsubsection{Perceived Quality and Customer Satisfaction}

The regression estimates of the current research confirm the significant positive relationship of perceived quality on customer satisfaction. The statistical figures of Beta value and Significant value are $(\beta=0.442),(p<0.001)$ respectively. The adjusted $R$ square of this relationship is 0.190 . So our study approves $\mathrm{H} 1$.

\subsubsection{Perceived Quality, Customer Satisfaction, Brand Trust and Brand Loyalty.}

The regression results of the research represent a significant positive relationship between perceived quality and brand trust. The Beta value is $(\beta=0.277)$ with significant value of $(p<$ $0.01)$. So, $\mathrm{H} 4$ is also supported. There is also found a significant positive relationship between customer satisfaction and brand loyalty. The Beta value of this relation is $(\beta=0.267)$, having significant value $(\mathrm{p}<0.01)$. Hence, H5 is also proved. Similarly, there have observed a significant positive relationship between brand trust and brand loyalty. The beta value of this relation is $(\beta=0.187),(p<0.05)$. Therefore, H6 is accepted by this study. The adjusted $\mathrm{R}$ square of above relationships is 0.321 .

\section{CONCLUSION}

Our research strongly approved the proposed hypothesis of our research model. It is concluded from our research that perceived quality; customer satisfaction and brand trust collectively lead to brand loyalty. The regression analysis of these variables demonstrates a strong relationship between the said variables and brand loyalty. This study also approved that brand name and brand communication are the constructs of brand trust that ultimately lead to brand loyalty.

\section{LIMITATIONS}

As this research is based on a limited sample size so we cannot generalize the findings of this research. This research is conducted only a specific geographical area Bahawalpur, Pakistan. So, there may be a difference in results if the same research is conducted in other areas of the country or even the world. We have focused services sector generally and telecommunication sector particularly to prove the proposed relationships. In contrast, if the same relationships would be applied in the sectors other than telecommunication, the results would have been different.

\section{RECOMMENDATIONS}

This research study provides numerous applications for the existing cellular service providers generally and in Pakistan specifically. Brand communication, Brand name and Brand trust has shown a very significant impact in creating brand loyalty. So, the cellular service providers would trigger their advertising and promotional activities to multiply their sales which would in turn enhance their profits by making the customers loyal with the help of 
enhancing their trust and relationship.

In developing countries, the markets are going to be matured like developed countries. It is very difficult for the companies to attract the new customers and retain the old one due to intensive competition for making the above average profits. The simple conventional marketing strategies are not enough without focusing the key areas of development. So, this study provides an opportunity to focus on the key antecedents of brand loyalty.

\section{REFERENCES}

1) Aaker, D.A. (1991), Managing Brand Equity, The Free Press, New York, NY.

2) Aaker, David A. (1996), "Measuring Brand Equity Across Products and Markets," California Management Review, 38(Spring), 102-20.

3) Andaleeb, S. S. (1992) The trust concept: Research issues for channels of distribution",Research in Marketing, Vol.11, No.1, pp.1-34.

4) Berry, L. L. (1995) "Relationship marketing of services growing interest, emerging perspectives", Journal of the Academy of Marketing Science, Vol.23, No.4, pp.236-245.

5) Bennett, R. and Rundle-Thiele, S. (2000), "Attitudinal loyalty - personality trait or brand-specific?”, ANZMAC 2000 Visionary Marketing for the 21st Century: Facing the Challenge, Griffith University School of Marketing and Management, pp. 97-101.

6) Barney, J. B. \& Hansen, M. H. (1994) "Trustworthiness as a source of competitive advantage", Strategic Management Journal, Vol.15 (Special issue), pp.175-190.

7) . Bitner, M. J., \&Hubbert, A. R. (1994). Encounter satisfaction versus overall satisfaction versus quality. In R. T. Rust \& R. L. Oliver (Eds.), Service quality: New directions in theory and practice (pp. 72-94). London: Sage.

8) Baldinger AL, Rubinson J (1996). Brand loyalty: the link betweenattitude and behavior. J. Adv. Res., 36(6): 22-34.

9) Bennet, R., \& Rundle-Thiele, S. (2004). Customer satisfaction should not be the onlygoal. Journal of Service Marketing, 18(7), 514-523.

10) ChaudhuriArjun,HolbrookB.Moris, (2001), "The Chain Of Effects From Brand Trust And Brand Affects To BrandPerformance: The Role of Brand Loyalty", Journal of Marketing Vol.65, p.81-93

11) Chao, P. (2008). Exploring the nature of the relationships between service qualityand customer loyalty: An attribute-level analysis. The Service Industries Journal,28(1), 95-116.

12) Duncan, Tom And Moriarity Sandra, E, (1998), "A Communication-Based Marketing Model for ManagingRelationships", Journal of Marketing, Vol.62, April 1998, S.1-13 


\section{Macrothink}

Journal of Public Administration and Governance ISSN 2161-7104 2013, Vol. 3, No. 3

13) Doney, Patricia M. and Joseph P. Cannon, (1997), "An Examination of the Nature of Trust in Buyer-SellerRelationships," Journal of Marketing, 61 (April), 35-51.

14) Dasgupta, P. (1988) "Trust as a Commodity", in Trust: Making and Breaking CooperativeRelations, ed. Diego Gambetta, New York: Basil Blackwell, pp.49-72.

15) Dwyer, F. R., Schurr, P.H. \& Oh, S. (1987) "Developing buyer-seller relationship", Journal ofMarketing, Vol.51, No.2, pp.11-27.

16) Dyson, P., Farr, A. \& Hollis, N. (1996) "Understanding, measuring, and using brand equity.Journal of Advertising Research, Vol.36, No.6, pp.9-21.

17) Day, G.S. (1996), "A two-dimensional concept to brandloyalty", Journal of Advertising, Vol. 30 No. 9, pp. 29-35.

18) Gronroos, C. (1984). A service quality model and its marketing implications.European Journal of Marketing, 8(4), 36-44.

19) Groth, J.C. and McDaniel, S.W. (1993), "The exclusive valueprinciple", Journal of Consumer Marketing, Vol. 10 No. 1,pp. 10-16.

20) Hult GTM, Ketchen D (2001). Does market orientation matter? a test ofthe relationship of positional advantage and performance. Strateg.Manage. J., 22(9): 899-906.

21) Jacoby, J. \& Olson, J.C. (1970). Anattitudinal model of brand loyalty:conceptual underpinnings andinstrumentation research. Presented at theUniversity of Illinois Conference on AttitudeResearch and Consumer Behaviour,Urbana, Illinois

22) Kotler, P. (1997) Marketing Management, 9thEdition, Prentice Hall Inc., USA.

23) Kohli, C. and Thakor, M. (1997) "Branding Consumer Goods: Insights from Theory andPractice", Journal of Consumer Marketing, Vol.14, pp.206-219.

24) Matzler, K., Grabner-Kräuter, S., \&Bidmon., S. (2008) "Risk aversion and brand loyalty: thel mediating role of brand trust and brand affect", The Journal of Product and BrandManagement, Vol.17, No.3, pp.154-162.

25) Morgan M.Robert\& Hunt D. Shelby, (1994), "The Commitment-Trust Theory of Relationships Marketing”, Journal ofMarketing, Vol.58 (July 1994), 20-38

26) Morgan, R. M. \& Hunt, S. D. (1994) "The commitment-trust theory of relationship marketing",Journal of Marketing, Vol.58, No.3, pp.20-38.

27) Larzelere, Robert and Huston, Ted L. (August 1980) "The Dyadic Trust Scale: TowardUnderstanding Interpersonal Trust in Close Relationships", Journal of Marriage and theFamily, pp.595-604

28) Lewis, J.D. and Weigert, A. (1985) "Trust as a Social Reality", Social Forces, Vol.63, pp.967-985. 


\section{Macrothink}

Journal of Public Administration and Governance ISSN 2161-7104 2013, Vol. 3, No. 3

29) Low, G. S., \& Lamb, C. W. (2000). The measurement and dimensionality of brandassociations. Journal of Product and Brand Management, 9(6), 350-368.

30) LaBarbera PA, Mazursky D (1983). A longitudinal assessment ofconsumer satisfaction/dissatisfaction: The dynamic aspect of thecognitive process. J. Mar. Res., 20(4): 393-404

31) Moorman, Christine, Deshpande, Rohit and Zaltman, Gerald, (1993), "Factors Affecting Trust In Market ResearchRelationships", Journal of Marketing, Vol.57, S.81-101

32) Oliver RL (1980). A cognitive model of the antecedents andconsequences of satisfaction decisions. J. Mar. Res., 17(4): 460-469.

33) Oliver, R. L. (1993). Cognitive, affective and attribute bases of the satisfactionresponse. Journal of Consumer Research, 20(3), 418-430.

34)_Oliver, Richard L. (1999), "Whence Consumer Loyalty?" Journal of Marketing, 63 (Special Issue), p.33-44.

35) Panda, Tapan K. (2004) "Consumer Response to Brand Placements in Films Role of Brand Congruity and Modality ofPresentation in Bringing Attitudinal Change Among Consumers with Special Reference to Brand Placements in Hindi Films" SouthAsian Journal of Management. New Delhi: Oct-Dec 2004. Vol. 11, Iss. 4; pg. 7, 19 pgs

36) Pritchard, M.P., Havitz, M.E. and Howard, D.R. (1999), “Analyzing the commitment-loyaltylinks in service contexts", Journal of the Academy of Marketing Science, Vol. 27 No. 3,pp. 333-48.

37) Russell-Bennett R, McColl-Kennedy JR, Coote LV (2007). Involvement,satisfaction and brand loyalty in a small business services setting. J.Bus. Res., 60(12): 1253-1260.

38) Reicheld, F. F. \&Schefter, P. (2000) "E-loyalty: Your secret weapon on the web", HarvardBusiness Review, Vol.78, No.4, pp.105-113.

39) Rempel, John K., John G. Holmes, and Mark P. Zanna (1985) "Trust in Close Relationships",Journal of Personality and Social Psychology, Vol.49, No.1, pp.95-112.

40) Rizwan, M., Usman, A., Hussain, T., Shafiq, A., Rauf, S. \& Ayaz, Q., (2013) The Impact of the Perceived Quality, Customer Satisfaction, Brand Trust and Contextual Factors on Brand Loyalty, International Journal of Research in Commerce and Management, 4(3), 83-89

41) Rizwan, M., Ahmad, W., Tahir, S., Ali, S., Naz, A., Ain, Q. \& Peerzada, P. (2013) Antecedents of Brand Loyalty: An Empirical Study from Pakistan, International Journal of Research in Commerce, Economics and Management, 3(3), 169-174

42) Rotter, Julian B. (1980) "Interpersonal Trust, Trustworthiness, and Gullibility", AmericanPsychologist, Vol.35, No.1, pp.1-7. 
43) Rodriguez del Bosque, I., \& San Martin, H. (2008). Tourist satisfaction a cognitiveaffectivemodel. Annals of Tourism Research, 35(2), 551-573

44) WONG FOONG YEE AND bYAHYAH SIDEK (2008) Influence of Brand Loyalty on Consumer SportswearInt. Journal of Economics and Management 2(2): 221 - 236 (2008)

45) Yoo, B., Donthu, N., \& Lee, S. (2000). An examination of selected marketing mixelements and brand equity. Journal of the Academy of Marketing Science, $28(2), 195-211$.

46) Yoo B, Donthu N (2001). Developing and validating a multidimensionalconsumer-based brand equity scale. J. Bus Res., 52(1): 1-14.

47) Zeithaml, V. A. (1988). Consumer perceptions of price, quality, and value: Ameans-end and synthesis of evidence. Journal of Marketing, 52(3), 2-22.

48) Zhu Z, Nakata C (2007). Reexamining the link between customerorientation and business performance: the role of informationsystems. J. Mar. Thro. Pract., 15(3): 187-203. 